\title{
Behavioral modifications by a large- northern herbivore to mitigate warming conditions
}

Jyoti S. Jennewein ${ }^{1 *}$ (D), Mark Hebblewhite ${ }^{2}$, Peter Mahoney ${ }^{3}$, Sophie Gilbert ${ }^{4}$, Arjan J. H. Meddens ${ }^{5}$, Natalie T. Boelman ${ }^{6}$, Kyle Joly ${ }^{7}$, Kimberly Jones ${ }^{8}$, Kalin A. Kellie ${ }^{9}$, Scott Brainerd ${ }^{10}$, Lee A. Vierling ${ }^{1}$ and Jan U. H. Eitel ${ }^{1,11}$

\begin{abstract}
Background: Temperatures in arctic-boreal regions are increasing rapidly and pose significant challenges to moose (Alces alces), a heat-sensitive large-bodied mammal. Moose act as ecosystem engineers, by regulating forest carbon and structure, below ground nitrogen cycling processes, and predator-prey dynamics. Previous studies showed that during hotter periods, moose displayed stronger selection for wetland habitats, taller and denser forest canopies, and minimized exposure to solar radiation. However, previous studies regarding moose behavioral thermoregulation occurred in Europe or southern moose range in North America. Understanding whether ambient temperature elicits a behavioral response in high-northern latitude moose populations in North America may be increasingly important as these arctic-boreal systems have been warming at a rate two to three times the global mean.
\end{abstract}

Methods: We assessed how Alaska moose habitat selection changed as a function of ambient temperature using a step-selection function approach to identify habitat features important for behavioral thermoregulation in summer (June-August). We used Global Positioning System telemetry locations from four populations of Alaska moose ( $n=$ 169) from 2008 to 2016. We assessed model fit using the quasi-likelihood under independence criterion and conduction a leave-one-out cross validation.

Results: Both male and female moose in all populations increasingly, and nonlinearly, selected for denser canopy cover as ambient temperature increased during summer, where initial increases in the conditional probability of selection were initially sharper then leveled out as canopy density increased above $\sim 50 \%$. However, the magnitude of selection response varied by population and sex. In two of the three populations containing both sexes, females demonstrated a stronger selection response for denser canopy at higher temperatures than males. We also observed a stronger selection response in the most southerly and northerly populations compared to populations in the west and central Alaska.

(Continued on next page)

\footnotetext{
*Correspondence: jjennewein@uidaho.edu

'Department of Natural Resources and Society, University of Idaho, Moscow,

ID, USA

Full list of author information is available at the end of the article
}

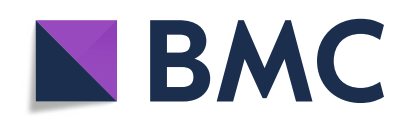

( ) The Author(s). 2020 Open Access This article is licensed under a Creative Commons Attribution 4.0 International License, which permits use, sharing, adaptation, distribution and reproduction in any medium or format, as long as you give appropriate credit to the original author(s) and the source, provide a link to the Creative Commons licence, and indicate if changes were made. The images or other third party material in this article are included in the article's Creative Commons licence, unless indicated otherwise in a credit line to the material. If material is not included in the article's Creative Commons licence and your intended use is not permitted by statutory regulation or exceeds the permitted use, you will need to obtain permission directly from the copyright holder. To view a copy of this licence, visit http://creativecommons.org/licenses/by/4.0/. The Creative Commons Public Domain Dedication waiver (http://creativecommons.org/publicdomain/zero/1.0/) applies to the data made available in this article, unless otherwise stated in a credit line to the data. 


\begin{abstract}
(Continued from previous page)
Conclusions: The impacts of climate change in arctic-boreal regions increase landscape heterogeneity through processes such as increased wildfire intensity and annual area burned, which may significantly alter the thermal environment available to an animal. Understanding habitat selection related to behavioral thermoregulation is a first step toward identifying areas capable of providing thermal relief for moose and other species impacted by climate change in arctic-boreal regions.
\end{abstract}

Keywords: Climate change, Behavioral thermoregulation, Thermal stress, Ambient temperature, Habitat selection, Wildlife, Alces alces

\section{Background}

Global temperatures are drastically increasing [36], which directly affect animal behavior and fitness $[9,88$, 91]. When ambient temperatures rise above an animal's thermal neutral zone, they use physiological and behavioral mechanisms to dissipate heat and mitigate thermal stress. For instance, additional energy may be spent to augment the cardiovascular and respiratory systems enabling evaporative cooling but may also lead to dehydration $[16,54,73]$. Consequentially, increases in ambient temperature may contribute to a negative energy balance within an animal $[5,85,87]$. Energetic requirements of mammals vary by season and traits (e.g., body mass, lactation). Summer is an important season for mammals as they need to recover from winter food deficits, lactate and rear young, and store fat [14, 75, 85]. Climate change puts further stress on these important activities, which may, in turn, limit the ability of mammals to meet energetic requirements for reproduction and survival $[25,50,90]$. Recent work suggests that large-bodied mammals respond more strongly to climate change, when compared to smaller-bodied mammals, through contraction or expansion of elevational ranges and also experience increased extinction risk [53].

Moose (Alces alces) are an important, large-bodied mammal vulnerable to increasing temperatures because they are well-adapted to cold climates [73, 76]. Moose also act as ecosystem engineers, by regulating forest carbon and structure, below ground nitrogen cycling processes, and predator-prey dynamics [12, 15, 48, 55]. According to the seminal physiological study by Renecker and Hudson [73], moose reached their upper critical temperature threshold at $14{ }^{\circ} \mathrm{C}$ in summer where they increased their heart and respiration rates, while open-mouthed panting began at $20^{\circ} \mathrm{C}$. However, recent works call these thresholds into question and suggest there is no static temperature threshold where free-ranging moose become heat stressed [83, 84]. Similarly, behavioral changes are often observed at temperatures that exceeds the upper critical summer threshold proposed by Renecker and Hudson [73] [11, 56].

Behavioral alterations elicited by changes in temperature influence both resource selection patterns and movement rates. For example, previous studies showed that during hotter periods, moose displayed stronger selection for riparian or wetland habitats [74, $80]$, taller and denser forest canopies that provide thermal cover [20, 56, 88], and minimized exposure to solar radiation [54]. Additionally, moose may also decrease their activity and movement rates in response to warmer daytime temperatures $[58,80]$.

Moose thermoregulatory behaviors are indeed a 'hot topic' in applied ecology because of rising temperatures related to climate change and their important ecosystem role (e.g., [56, 58, 80]). However, most previous studies occurred in Europe or the southern end of moose range in North America [50, 56, 88]. Understanding whether ambient temperature elicits a behavioral response in high-northern latitude (i.e., $\geq 60^{\circ} \mathrm{N}$ ) moose populations in North America may be increasingly important as these arctic-boreal systems have been warming at a rate two to three times the global mean $[2,36,77,95]$ and current projections anticipate continued increases in temperature [36, 51]. Thus, it is important to explore how movement patterns of moose, a heat-sensitive large-bodied mammal, are influenced by changes in temperature at the northern extent of their range.

Accordingly, our study objective was to assess Alaska moose (Alces alces gigas) habitat selection as a function of ambient temperature. We tested the hypothesis that moose modified resource selection in response to ambient temperature as predicted by physiological models. To accomplish this, we used Global Positioning System (GPS) -telemetry locations from four Alaska moose populations ( $n=169$ moose; Fig. 1 \& Table 1 ) from 2008 to 2016 that were located in four unique ecoregions [65]. We combined moose GPS locations with remotely sensed products important to thermoregulatory behaviors. We analyzed only summer months (June-August) because of their importance in moose life history and because thermal stress is most likely to occur in summer $[23,88]$. Each population was analyzed independently and separated into male and female subsets because fine-scale movements vary by sex and local habitat characteristics [41, 43, 49]. We predicted that Alaska moose exhibit a detectable behavioral response to increasing 


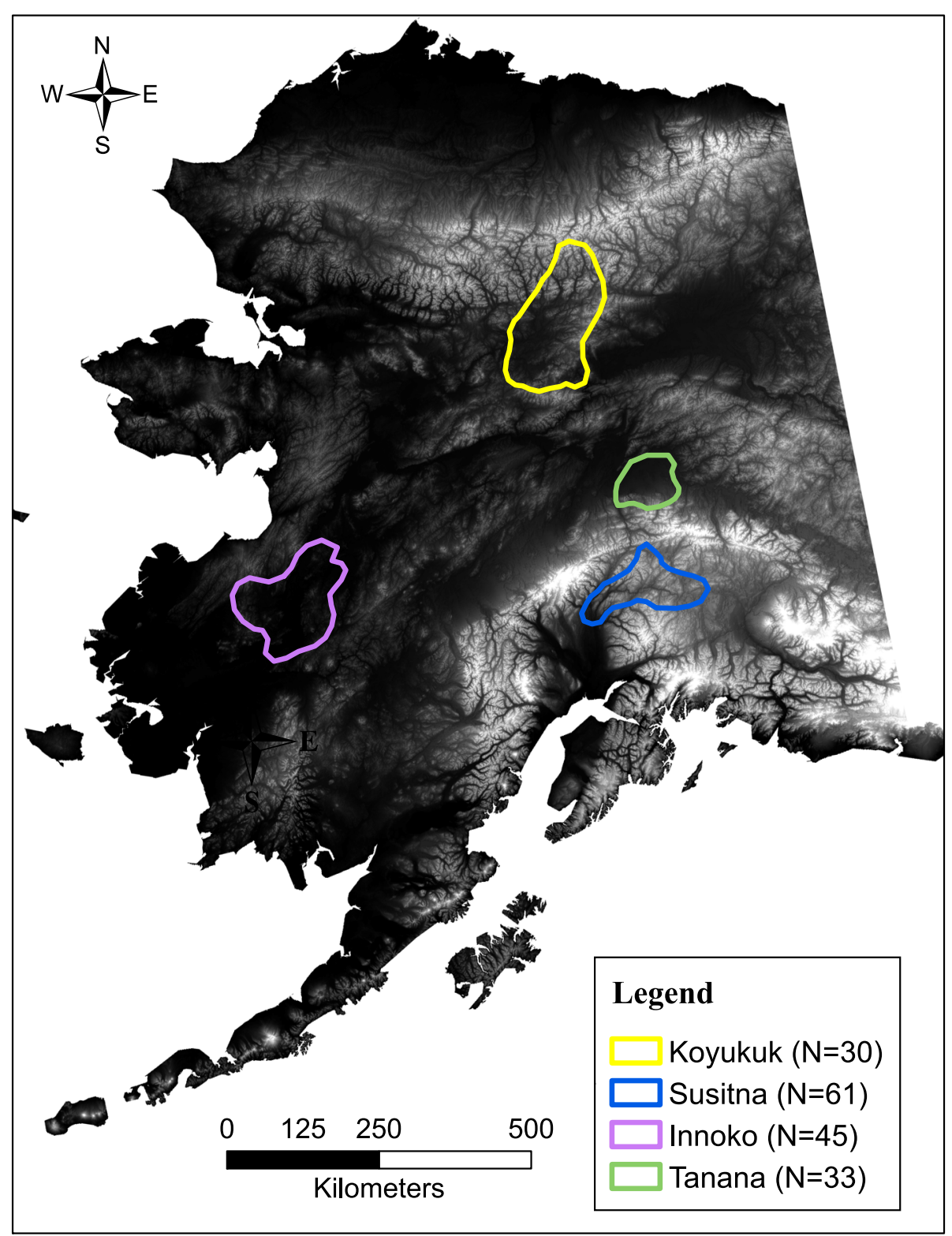

Fig. 1 Moose (Alces alces gigas) study area locations in four distinct ecoregions of Alaska, USA. In total, 169 moose were included in these analyses (111 females; 58 males)

summer temperatures, and, that as temperature increased, moose would select for cooler locations, such as thermal refugia provided through increased canopy cover, areas closer to water, and/or low exposure to solar radiation.

\section{Methods}

\section{Study areas}

All four study areas span a mixture of subarctic and arctic boreal forest vegetation including black spruce (Picea mariana), alders (Alnus spp.), willows (Salix spp.), Alaska birch (Betula neoalaskaa), white spruce (Picea glauca), quaking aspen (Populus tremuloides), and balsam poplar (Populus balsmifera). The upper Koyukuk region located in the Brooks Mountain Range (Fig. 1) is rugged and varies from 500 to $2600 \mathrm{~m}$ above sea level [1]. Wildfire is common in this region, which experiences strongly continental climate patterns where summers are short, but temperatures can exceed $30^{\circ} \mathrm{C}$ [41]. Average daily summer (June-August) temperature ranged from $7.5^{\circ} \mathrm{C}$ to $15^{\circ} \mathrm{C}$ from 1986 to 2016 [64]. The Tanana Flats region is located south of Fairbanks, where the alluvial plane from the Alaska Mountain Range slopes northward making meandering rivers and oxbow lakes common [1]. Elevation ranges from 0 to $700 \mathrm{~m}$, however the highest elevations occurred in the northern 
Table 1 Summaries of Alaska moose (Alces alces gigas) Global Positioning System (GPS) datasets by study area. Information on the number of fixes and the fix success rate are specific to summer (June 1 - August 31). The number of clusters for each populationsex partition refer to the unique combination of individual-year, which were used in our conditional logistic regression models as a clustering variable for estimating robust variance estimates using generalized estimating equations

\begin{tabular}{|c|c|c|c|c|c|c|c|}
\hline Dataset & $\begin{array}{l}\text { Number of } \\
\text { moose }\end{array}$ & $\begin{array}{l}\text { Number females } \\
\text { (clusters) }\end{array}$ & $\begin{array}{l}\text { Number males } \\
\text { (clusters) }\end{array}$ & Years & $\begin{array}{l}\text { Fix rate } \\
\text { (hours) }\end{array}$ & $\begin{array}{l}\text { Fix } \\
\text { success }\end{array}$ & $\begin{array}{l}\text { Number of } \\
\text { fixes }\end{array}$ \\
\hline \multirow[t]{2}{*}{ Koyukuk } & \multirow[t]{2}{*}{30} & \multirow[t]{2}{*}{$19(45)$} & \multirow[t]{2}{*}{$11(22)$} & \multirow{2}{*}{$\begin{array}{l}2008- \\
2013\end{array}$} & \multirow[t]{2}{*}{8} & \multirow[t]{2}{*}{$91 \%$} & F- 11,324 \\
\hline & & & & & & & M- 3949 \\
\hline \multirow[t]{2}{*}{ Susitna } & \multirow[t]{2}{*}{61} & \multirow[t]{2}{*}{$38(71)$} & \multirow[t]{2}{*}{$23(36)$} & \multirow{2}{*}{$\begin{array}{l}2012- \\
2016\end{array}$} & \multirow[t]{2}{*}{8} & \multirow[t]{2}{*}{$98 \%$} & F- 14,984 \\
\hline & & & & & & & M-6003 \\
\hline \multirow[t]{2}{*}{ Innoko } & \multirow[t]{2}{*}{45} & \multirow[t]{2}{*}{$21(63)$} & \multirow[t]{2}{*}{$24(65)$} & \multirow{2}{*}{$\begin{array}{l}2010- \\
2014\end{array}$} & \multirow[t]{2}{*}{$4^{\mathrm{a}}$} & \multirow[t]{2}{*}{$95 \%$} & F- 2319 \\
\hline & & & & & & & M- 1987 \\
\hline Tanana & 33 & $33(145)$ & 0 & $\begin{array}{l}2011- \\
2016\end{array}$ & $3.5^{\mathrm{a}}$ & $99 \%$ & F- 21,530 \\
\hline \multirow[t]{2}{*}{ Totals: } & \multirow[t]{2}{*}{169} & \multirow[t]{2}{*}{111} & \multirow[t]{2}{*}{58} & \multirow[t]{2}{*}{-} & \multirow[t]{2}{*}{-} & \multirow[t]{2}{*}{$96 \%$} & $F-50,157$ \\
\hline & & & & & & & M- 11,939 \\
\hline
\end{tabular}

${ }^{a}$ data with less than 8 -h fix rates were aggregated to near $8-\mathrm{h}$ fix rates

portion of the Alaska Mountain Range [1]. The Tanana region experiences dry-continental climate, and average daily summer temperature ranged from $11^{\circ} \mathrm{C}$ to $19.5^{\circ} \mathrm{C}$ from 1986 to 2016 [64]. The Innoko region lies in southwest Alaska and includes a portion of the lower Yukon River. Meandering waterways, oxbow lakes and floods are common in the lowlands while upland areas experience more wildfire disturbance [67]. Elevation varies little $(30-850 \mathrm{~m})$ and average daily summer temperatures ranged from $9.5^{\circ} \mathrm{C}$ to $17.5^{\circ} \mathrm{C}$ from 1989 to 2016 [64]. The Susitna moose range lies south of Alaska Mountain Range, and is characterized by numerous wetlands, hilly moraines, black spruce woodlands, and mountains. Elevation varies widely from 400 to $3500 \mathrm{~m}$. This region is primarily located in temperate-continental climate, with some exposure to temperate coastal climates in the southern portion of the range [1]. Average daily summer temperatures ranged from $11.5^{\circ} \mathrm{C}$ to $19^{\circ} \mathrm{C}$ from 1988 to 2016 in this region [64].

\section{Moose data}

All capture protocols and handling protocols adhered to the Alaska Animal Care and Use Committee approval process $(\# 07-11)$ as well as the Institutional Animal Care and Use Committee Protocol (\#09-01). Moose in all regions were darted from helicopter (Robison R-44) and injected using carfentanil citrate (Wildnil ${ }^{\bullet}$ Wildlife Pharmaceuticals, Incorporated, Fort Collins, CO) and xylazine hydrochloride (Anaset ${ }^{\oplus}$; Lloyd Laboratories, Shenandoah, IA). Moose were instrumented with GPS radio-collars with three and a half to eight-hour fix rates (Table 1). Specifically, moose were fitted with the following collars from Telonics Inc. (Telonics, Mesa, AZ): Koyukuk - GW-4780, Tanana -TGW-4780-3, Susitna TGW-4780-2, Innoko -CLM-340.

\section{Statistical analyses Habitat selection}

We used a step-selection function (SSF) to assess moose behavioral responses to changing temperatures. SSF's model habitat selection in a used-available design that accounts for changing availability of resources at any point in time $[27,86]$. We aggregated moose datasets to a near eight-hour fix rate to enable regional comparisons of behavior (Table 1). We chose this modeling framework because it allows for assessments of fine-scale habitat selection, and the effect of temperature on large herbivore movement behavior are most pronounced at fine to intermediate spatial and temporal scales [89]. To sample availability, we generated ten-paired available locations based on empirical distributions of an individual's step length and turning angles between sampling intervals, which were estimated using the "ABoVENASA" R package [29]. We used conditional-logistic regression (CLR, [35]) in the "survival" $\mathrm{R}$ package [82] to compare each used location with the concurrent available locations at the same point in time and space (i.e., one stratum contained one used point and ten randomly generated available points). The equation can be written as:

$$
w *(\mathrm{x})=\frac{\exp (\beta 1 \mathrm{x} 1+\beta 2 \mathrm{x} 2+\ldots+\beta \mathrm{nxn}+e)}{1+\exp (\beta 1 \mathrm{x} 1+\beta 2 \mathrm{x} 2+\ldots+\beta \mathrm{nxn}+e)}
$$

where $w^{*}(x)$, the relative probability of selection, is dependent on habitat covariates $X_{1}$ through $X_{\mathrm{n}}$, and their estimated regression coefficients $\beta 1$ to $\beta n$, respectively. Steps with higher $w^{*}(x)$ indicate a greater chance of selection. CLR compares strata (i.e., one used point and ten available points) individually, which enabled us 
to assess selection of fine-scale habitat features rather than broader-scale landscape characteristics [6]. We did not directly incorporate random effects into our SSF models as the analytical techniques for doing this are sparse and often computationally prohibitive for complex model sets [61]. In our models, we would have a needed to incorporate a random effect of individual for each covariate in the model - the equivalent of random slopes. We believe this would likely have led to convergence issues as our models are already complex (see section regarding temperature interaction terms). Instead, we fit our CLR models with generalized estimating equations (GEE) using a clustering variable of "animal-year" to split the data into statistically independent clusters. This allowed us to account for lack of independence between steps within an individual for a given summer, and provided unbiased (i.e., robust) variance estimates provided there are at least 20 independent clusters and preferably 30 [71]. Our data all had at least 20 unique animal year clusters, and all but one had greater than 30 (Table 1).

\section{Habitat covariates}

We obtained temperature estimates from the North American Regional Reanalysis (NARR) as opposed to weather stations. NARR provides a suite of highlytemporally dynamic (eight times daily; $32 \mathrm{~km}$ ) set of meteorological variables [57]. We annotated NARR temperature estimates using the environmental-data automated track annotation (Env-DATA) system available from Movebank [21]. To ensure accuracy of these temperature estimates, we performed a validation exercise on the two populations of moose which included temperature sensors on their collars (Innoko and Koyukuk). We found a moderate relationship between the two (Supplementary material (S) $1 ; R^{2}=0.47-0.58$, RMSE $=3.88-4.43^{\circ} \mathrm{C}$ ). NARR temperature estimates represent an ambient, neighborhood temperature, allowing us to investigate how moose respond to ambient variation in temperature via fine-scale selection for environmental characteristics that are likely to create cooler microclimates. We excluded ambient temperature as a main effect within CLR models because it did not vary within strata, and only included it as an interaction term with other covariates.

Moose may move to areas that provide thermal cover when temperatures increase such as denser canopied forests [56]. In our models, a United States Geological Survey (USGS) percent canopy product for 2010 (30 m cell size, [31]) was used as an index of thermal cover. Moose use canopy cover for purposes other than thermoregulation such as predator avoidance [85]. However, by considering the interaction between temperature and canopy cover, it is likely that we captured behavioral thermoregulation in our models.

We assessed the importance of water habitats in behavioral thermoregulation using a distance-to-water covariate. We estimated this covariate from Pekel et al.'s [68] percent global surface water map, which quantified global surface water from 1984 to 2015 . We used the $\mathrm{R}$ "raster" package [34] to estimate the Euclidian distance of the nearest water pixel ( $30 \mathrm{~m}$ cell size) from a given moose location. Elevation estimations (in meters) were extracted from the ArcticDEM (version 6, $5 \mathrm{~m}$ cell size [69];). The solar radiation index (SRI [46];) was estimated mathematically as a function of latitude, aspect, and slope using the "RSAGA" package [8] - which were derived from the ArcticDEM, with the resultant values representing the hourly extraterrestrial radiation striking an arbitrarily oriented surface [46].

We chose to consider only continuous covariates as predictors to represent habitat as dynamic and continuous (sensu [17]). Covariates were standardized by dividing them by two times their standard deviation [28], allowing coefficients to be directly comparable across models. Collinearity was assessed using Pearson correlation coefficients, if correlation coefficients between predictors exceeded 0.70 we excluded collinear metrics from being present in the same model [22].

\section{Two-way temperature interactions}

We considered both linear and nonlinear interactions between habitat covariates and ambient temperature as nonlinear processes are widespread in ecology particularly in response to climate change [13, 92]. In total, three model variants for each population-sex partition were considered: (1) a base model that included habitat covariates as described above with no interaction terms or consideration of temperature, (2) linear interaction models where habitat covariates sequentially interacted with temperature linearly, and (3) spline interaction models where habitat covariates sequentially interacted nonlinearly with temperature using natural cubic splines. Because nonlinear terms are at risk of overfitting models, we constrained any nonlinear relationships explored in the spline interactions to two or three knots in CLR models using the "splines" package [72].

\section{Habitat selection model evaluation and validation}

We evaluated model fit for each population-sex partition using the quasi-likelihood under independence criterion (QIC [66];) because it is well suited for case-control models [19]. Finally, predictive ability of model variants were assessed using leave-one-out cross validation (LOOCV), which is a k-fold cross validation variant [7] where each individual animal is sequentially left out and predicted based on the remaining data. Mean Spearman 
Table 2 Model evaluation (QIC) and cross validation (LOOCV) for female moose organized by population. Base models contain no temperature covariates, while spline models incorporate nonlinear interactions between a given covariate and ambient temperature. In this case, "Spline \%can2" refers to percent canopy interacted with ambient temperature with two spline segments, while "Spline \%can3" refers to percent canopy interacted with ambient temperature with three spline segments. Decreases in QIC indicate a better model fit while increases in LOOCV indicate more predictive ability

\begin{tabular}{|c|c|c|c|c|c|c|c|c|}
\hline & \multicolumn{2}{|c|}{ Koyukuk } & \multicolumn{2}{|c|}{ Susitna } & \multicolumn{2}{|c|}{ Innoko } & \multicolumn{2}{|l|}{ Tanana } \\
\hline & Base & Spline \%can2 & Base & Spline \%can2 & Base & Spline \%can2 & Base & Spline \%can3 \\
\hline$\overline{\mathrm{QIC}}$ & 47,070 & 46,918 & 70,707 & 70,423 & 73,361 & 73,184 & 102,854 & 102,746 \\
\hline$\Delta \mathrm{QIC}$ & - & -152 & - & -284 & - & -177 & - & -108 \\
\hline LOOCV & $68 \%$ & $69 \%$ & $62 \%$ & $64 \%$ & $60 \%$ & $63 \%$ & $36 \%$ & $46 \%$ \\
\hline$\Delta \mathrm{LOOCV}$ & - & $+1 \%$ & - & $+2 \%$ & - & $+3 \%$ & - & $+10 \%$ \\
\hline
\end{tabular}

Note: \%can = percent canopy cover

rank coefficients were used to determine the predictive ability of model variants. For each population-sex partition, the model with the highest correlation coefficients from LOOCV and lowest QIC was considered the best. All spatial processing and statistical analyses were conducted in the statistical software $R$ version 3.6.1 [72].

\section{Results}

In total, seven base, 28 linear interaction, and 28 spline interaction models were estimated. For the sake of parsimony, only the most biologically significant results are presented and summarized by sex and population. Elevation was collinear with distance-to-water in the Innoko population, we retained the latter because of its known importance in moose ecology $[74,80]$. In all but one case (Koyukuk males, S2), spline-based models where percent canopy interacted with temperature outperformed linear interaction and base models and are thus the only models discussed (Tables 2 and 3). In contrast to the strong habitat selection responses of moose for canopy cover, we did not find evidence for other behavioral thermoregulation strategies. For example, we found no support that Alaska moose altered resource selection with increasing summer temperatures in response to topography (i.e., more northerly, cooler slopes), elevation (with the exception of one population, S2), nor hydrology (i.e., by selecting to be closer to water).

\section{Females}

The best fit spline models across all four populations occurred when percent canopy interacted with temperature using two to three knots. These spline interaction models had significant improvements in model fit compared to both the base models $(\Delta \mathrm{QIC}=-$ 108 to - 284; Table 2) and the linear interaction models (not shown). Cross validation scores for spline interaction models experienced small to moderate improvements when compared to the base model $(\triangle \mathrm{LOOCV}=+$ $1 \%$ to $+10 \%$; Table 3 ).

In summer, female moose in all four regions selected for increased canopy cover nonlinearly as temperature increased (Fig. 2; S3). However, the magnitude of the selection response to thermal cover was most pronounced in the most southerly region (Susitna; $\beta_{\% \text { canopy } 1}=33.90$, $p<0.001 ; \beta_{\% \text { canopy } 2}=20.09, p<0.001$; Table 4 ) as well as the most northerly region (Koyukuk; $\beta_{\% \text { canopy1 }}=24.91$, $\left.p<0.001 ; \beta_{\% \text { canopy } 2}=20.03, p<0.001\right)$. Although the effect of canopy cover was reduced in both the Innoko moose $\left(\beta_{\% \text { canopy } 1}=14.82, p<0.001 ; \beta_{\% \text { canopy } 2}=9.01, p<\right.$ $0.001)$ and the Tanana moose ( $\beta_{\% \text { canopy1 }}=4.71, p<0.001$; $\beta_{\% \text { canopy } 2}=8.97, \beta_{\% \text { canopy } 3}=7.70, p<0.001$ ), both populations still revealed highly statistically significant results indicating female moose selected nonlinearly for increased canopy cover as temperature increased.

Female moose in the Koyukuk and Susitna regions also showed an increased affinity for water demonstrated

Table 3 Model model evaluation (QIC) and cross validation (LOOCV) for male moose summary of organized by population. See additional descriptors in Table 3

\begin{tabular}{|c|c|c|c|c|c|c|}
\hline & Koyuku & & Susitna & & Innoko & \\
\hline & Base & Spline \%can2 & Base & Spline \%can 2 & Base & Spline \%can2 \\
\hline$\overline{\mathrm{QIC}}$ & 18,583 & 18,529 & 27,919 & 27,777 & 62,946 & 62,849 \\
\hline$\Delta \mathrm{QIC}$ & - & -54 & - & -142 & - & -97 \\
\hline LOOCV & $42 \%$ & $45 \%$ & $57 \%$ & $62 \%$ & $50 \%$ & $56 \%$ \\
\hline$\Delta \mathrm{LOOCV}$ & - & $+3 \%$ & - & $+5 \%$ & - & $+6 \%$ \\
\hline
\end{tabular}




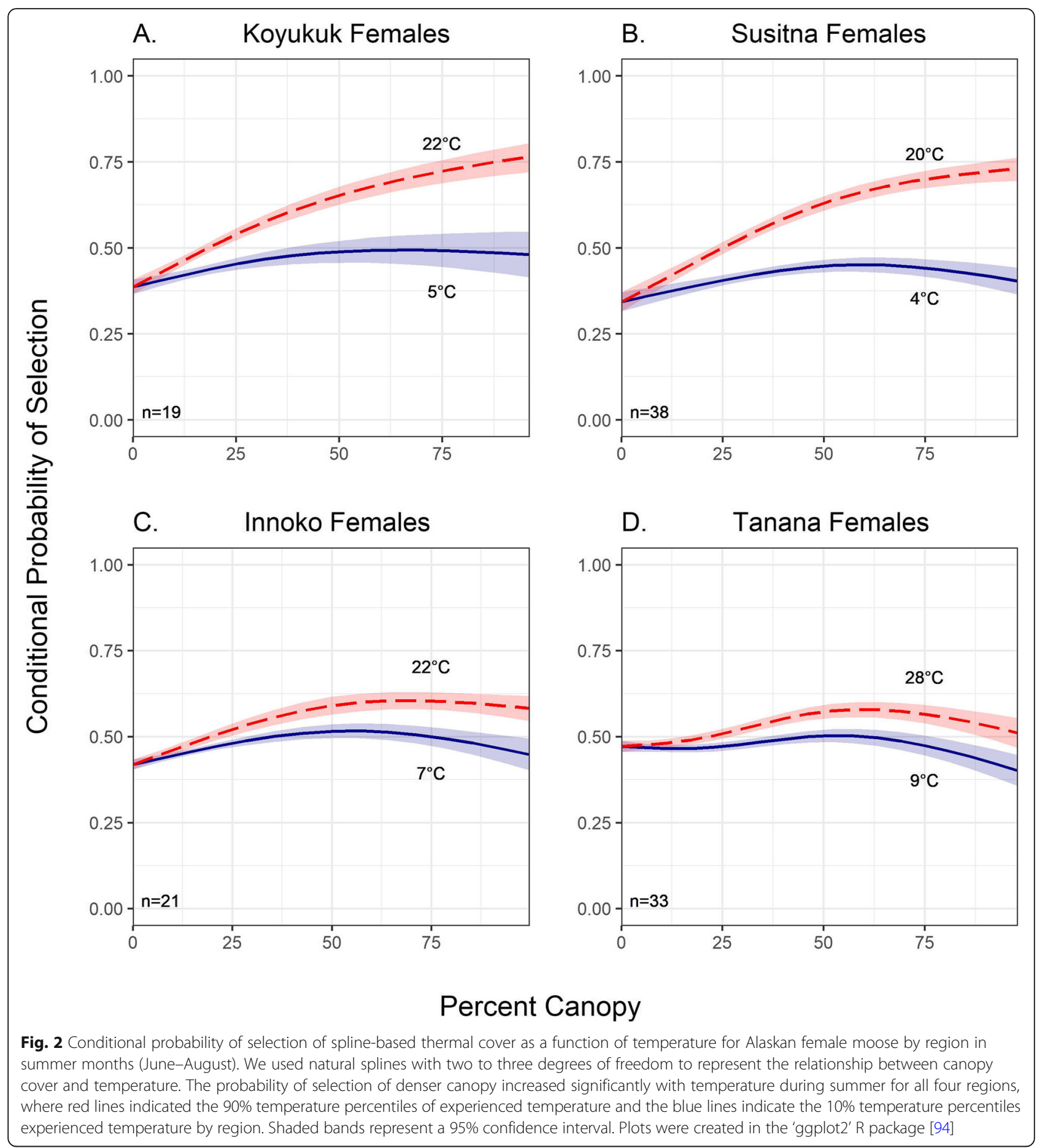

in the significant negative beta coefficients for the "distance-to-water" predictor (Table 4), suggesting that moose in these regions preferred to be closer to water. Additionally, we observed additional selection behaviors in the Innoko and Susitna female moose. Female moose in the Innoko population showed an avoidance of areas of high solar radiation $\left(\beta_{\mathrm{SRI}}=-0.18, p<0.001\right)$, while females in the Susitna population showed an avoidance of higher elevation locations $\left(\beta_{\text {elevation }}=-1.21, p<0.001\right)$, but these results were independent of temperature.

\section{Males}

For males, the best fit spline models in the Susitna and Innoko populations were also from percent canopy interacted with temperature $(\Delta \mathrm{QIC}=-142$ and -97 respectively; Table 3). For the Koyukuk males, the best fit 
Table 4 Best habitat selection models by population for female moose (Alces alces gigas) in Alaska from the step-selection function analysis. The best models across all four populations occurred when percent canopy interacted with temperature nonlinearly and are presented here. Natural spline (sp) predictors, where percent canopy interacted with temperature, have coefficients estimated for each line segment. Therefore, numbers one through three in the spline predictor terms represent an individual line segment. Only one of four populations (Tanana) has a third set of coefficients. In the Innoko population, elevation was collinear with distance-towater and was thus excluded. All predictors were standardized by dividing by two times their standard deviation, making coefficients directly comparable. Robust standard errors are reported

\begin{tabular}{lllll}
\hline Predictor & Population & & & \\
\cline { 2 - 5 } & $\begin{array}{l}\text { Koyukuk } \\
\text { Coefficient (SE) }\end{array}$ & $\begin{array}{l}\text { Susitna } \\
\text { Coefficient (SE) }\end{array}$ & $\begin{array}{l}\text { Innoko } \\
\text { Coefficient (SE) }\end{array}$ & $\begin{array}{l}\text { Tanana } \\
\text { Coefficient (SE) }\end{array}$ \\
\hline Elevation & $0.09(0.16)$ & $-1.21(0.25)^{\mathrm{b}}$ & NA & $0.28(0.39)$ \\
sp(Percent Canopy x Temperature) 1 & $24.91(3.7)^{\mathrm{b}}$ & $33.90(3.1)^{\mathrm{b}}$ & $14.82(3.32)^{\mathrm{b}}$ & $4.71(1.07)^{\mathrm{b}}$ \\
sp(Percent Canopy x Temperature)2 & $20.03(3.1)^{\mathrm{b}}$ & $20.09(1.9)^{\mathrm{b}}$ & $9.01(2.14)^{\mathrm{b}}$ & $8.97(2.22)^{\mathrm{b}}$ \\
sp(Percent Canopy x Temperature)3 & $\mathrm{NA}$ & $\mathrm{NA}$ & $\mathrm{NA}$ & $-7.70(1.97)^{\mathrm{b}}$ \\
Percent Canopy & $-13.90(2.2)^{\mathrm{b}}$ & $-16.60(1.6)^{\mathrm{b}}$ & $-7.90(1.92)^{\mathrm{b}}$ & $-4.80(1.21)^{\mathrm{b}}$ \\
Solar Radiation Index & $0.02(0.02)$ & $0.003(0.02)$ & $-0.18(0.02)^{\mathrm{b}}$ & $-0.0006(0.02)$ \\
Distance-to-Water & $-0.66(0.3)^{\mathrm{a}}$ & $-0.48(0.09)^{\mathrm{b}}$ & $-0.22(0.16)$ & $-0.09(0.07)$ \\
\hline
\end{tabular}

${ }^{\mathrm{a}} 0.05 ;{ }^{* * 0} 0.01 ;{ }^{\mathrm{b}} 0.001$

spline model came from elevation interacted with temperature (S2), but males in this region also saw improved model fit from percent canopy interacted with temperature $(\triangle \mathrm{QIC}=-54)$. Cross validation scores for spline interaction models (percent canopy interacted with temperature) in all three male populations experienced small to moderate increases when compared to the base model $(\triangle \mathrm{LOOCV}=+3 \%$ to $+6 \%)$.

Male moose in all three populations (no males were collared in the Tanana population, see Table 1) selected for increased canopy cover as temperature increased (Fig. 3; S3). However, like with the females, the response to selection of thermal cover was most pronounced in the most northerly region (Koyukuk; $\beta_{\% \text { canopy } 1}=27.84$, $p<0.001 ; \beta_{\% \text { canopy } 2}=24.30, p<0.001$; Table 5$)$ as well as the most southerly region (Susitna; $\beta_{\% \text { canopy } 1}=22.51, p<$ $\left.0.001 ; \beta_{\text {canopy } 2}=14.71, p<0.001\right)$. The effect of canopy cover was reduced in the Innoko males $\left(\beta_{\% \text { canopy } 1}=\right.$ $\left.13.02, p<0.001 ; \beta_{\% \text { canopy } 2}=8.50, p<0.001\right)$, yet the results still revealed highly statistically significant results indicating moose selected for increased canopy cover as temperature increased.

Additionally, male moose in the Susitna population showed increased selection of locations closer to water and, like their female counterparts, avoided areas of higher elevation $\left(\beta_{\text {elevation }}=-1.11, p<0.001\right)$. Similarly, Innoko males showed avoidance for areas with increased topographical solar radiation exposure $\left(\beta_{\mathrm{SRI}}=-0.12, p<\right.$ 0.001 ), but these selection behaviors were independent of temperature.

\section{Discussion}

Our results demonstrate that moose at the northern extent of their range altered habitat selection patterns in response to temperature. Across all populations and sexes, moose selected for denser canopy cover as temperature increased, which is consistent with previous studies [20, 56, 88], and our prediction that moose would select cooler locations as ambient temperature increased.

\section{Magnitude of selection response to temperature varied by sex and population}

Our habitat selection results also demonstrated that the magnitude of moose selection for dense canopy cover at higher temperatures varied between populations and sexes (Figs. 2 and 3; S2 and S3; Tables 4 and 5). In two (Innoko and Susitna) of the three populations containing both male and female moose, females demonstrated a stronger selection response for denser canopy at higher temperatures than males. This may be linked to calving and nursing demands on female moose [79] who may more strongly select for denser canopy cover to avoid spending calories to thermoregulate using physiological mechanisms. However, we were unable to distinguish between females with and without calves in this study. This likely influenced our results as females accompanied by their calves tend to increase selection for areas that provide cover for predator avoidance [24, 43] and drastically change their movements both before and after parturition [81].

We also considered whether population differences in selection strength may be related to the availability of thermal cover between regions (i.e., a functional response) where animals alter their habitat selection based on habitat availability [3, 63]. However, our results cannot entirely be explained by a functional response in habitat selection for thermal cover. For example, the 


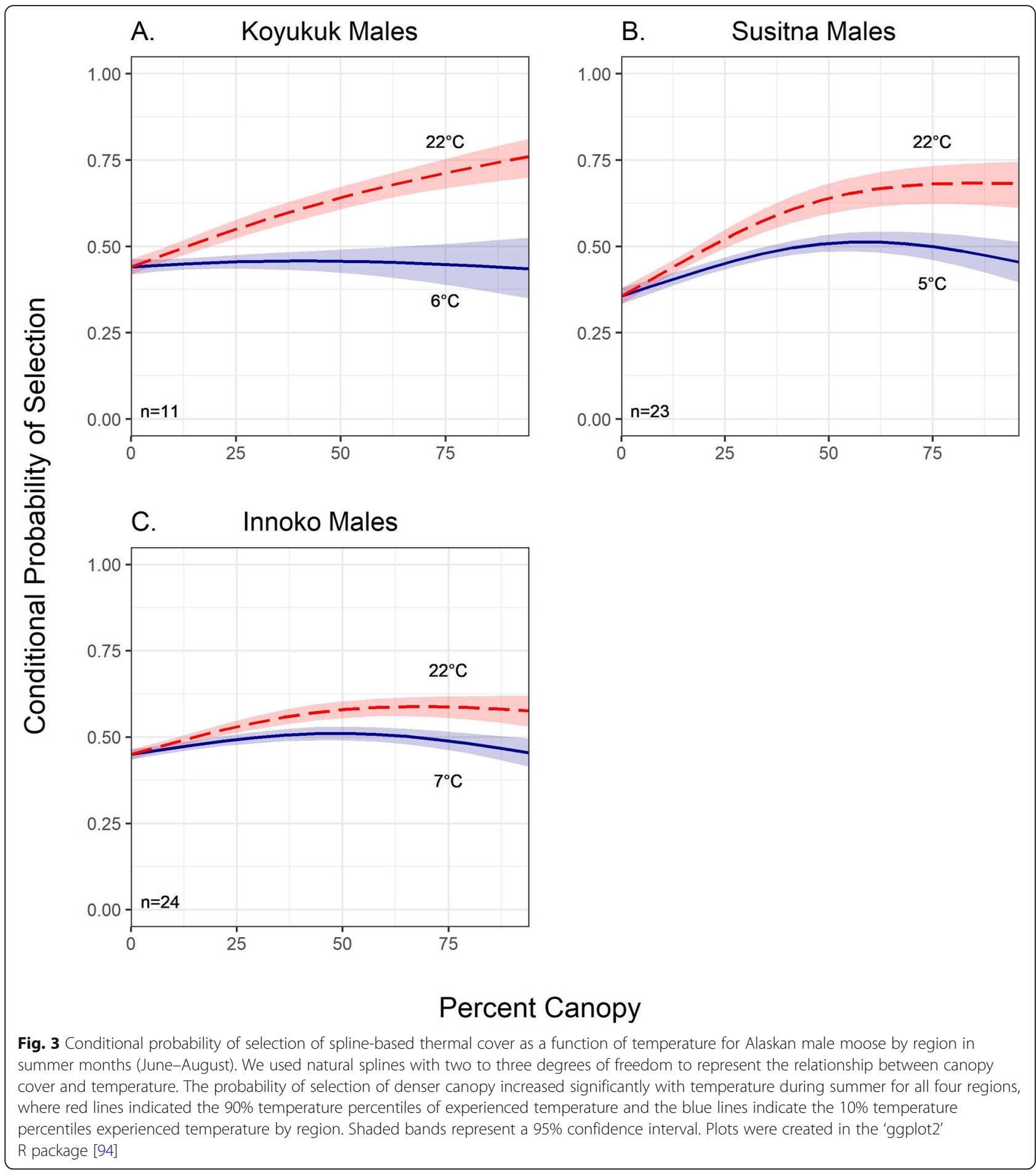

Koyukuk moose showed strong selection for thermal cover as temperature increased but also had the second lowest available canopy cover regionally (37.6\%; S4). Thus, we do not think a functional response per se explains regional differences in the selection strength, rather we anticipate that it is likely a combination of environmental factors interacting in complex ways to create a suite of unique habitat differences across regions (S5). However, to fully understand functional responses in habitat selection one must also consider the different spatial scales of selection [38, 63], as such responses are often evaluated at the landscape or home range scale [30, 32, 33, 60]. Thus, the lack of functional response of moose to canopy cover in our study may be 
Table 5 Best habitat selection models for male Alaska moose from the step-selection function analysis. Natural spline (sp) predictors, where percent canopy interacted with temperature, have coefficients estimated for each line segment. Numbers one and two in the spline predictors represent an individual line segment. All three populations had temperature-canopy interactions with two-line segments. In the Innoko population, elevation was collinear with distance-to-water and was thus excluded. All predictors were standardized by dividing by two times their standard deviation. Robust standard errors are reported

\begin{tabular}{|c|c|c|c|}
\hline \multirow[t]{3}{*}{ Predictor } & \multicolumn{3}{|l|}{ Population } \\
\hline & Koyukuk & Susitna & Innoko \\
\hline & Coefficient (SE) & Coefficient (SE) & Coefficient (SE) \\
\hline Elevation & $-0.45(0.37)$ & $-1.11(0.28)^{b}$ & NA \\
\hline sp(Percent Canopy ${ }^{a}$ Temperature) 1 & $27.84(4.6)^{b}$ & $22.51(5.5)^{\mathrm{b}}$ & $13.02(3.3)^{b}$ \\
\hline sp(Percent Canopy ${ }^{a}$ Temperature) 2 & $24.30(4.1)^{b}$ & $14.71(3.8)^{b}$ & $8.50(2.4)^{b}$ \\
\hline Percent Canopy & $-16.63(2.9)^{b}$ & $-11.81(3.1)^{\mathrm{b}}$ & $-17.60(2.04)^{b}$ \\
\hline Solar Radiation Index & $0.02(0.03)$ & $-0.005(0.003)$ & $-0.12(0.02)^{b}$ \\
\hline Distance-to-Water & $0.34(0.31)$ & $-0.59(0.11)^{b}$ & $-0.02(0.33)$ \\
\hline
\end{tabular}

${ }^{\mathrm{a}} 0.05 ;{ }^{* *} 0.01 ;{ }^{\mathrm{b}} 0.001$

related to the fine-scale nature of our analytical framework and not an absence of a functional response of moose to thermal cover.

\section{Implications of habitat selection results within a changing climate}

The consistent patterns of resource selection for thermal refugia under increasing temperatures found in this study may have important implications for moose resilience in arctic-boreal landscapes responding to increased temperatures from global climate change. For instance, landscape changes associated with wildfire are generally reducing canopy cover from coniferous species, and annual area burned in North American boreal systems doubled in the last half century [44], which is strongly linked to climate and annual weather patterns [37, 45]. Vegetation in interior Alaska now has less older spruce forests, the most common thermal refugia by moose, and a greater proportion of early successional vegetation than before 1990 [51]. Burn severity also plays a major role in how boreal forests recover after wildfire [26], where areas of low burn severity in black spruce stands tend to undergo self-replacement succession [39] and areas of high burn severity favor relay succession of deciduous species over black spruce because of increased exposure of mineral soil and reduced seedbank availability $[40,78]$. For moose, such changes in habitat structure may provide new forage resources [4, 47], but also may limit the available thermal refugia needed for behavioral thermoregulation immediately after disturbance events prior to vegetation regeneration, or in late spring (March-April) prior to budburst when moose have not yet shed their winter coats.

\section{Limitations and future work}

Our results showed moose did not select for areas closer to water as temperature increased, which differ from previous observations where moose sought wetland or riparian areas to thermoregulate $[76,80]$. We believe our results differed due to the spatial resolution $(30 \mathrm{~m}$ grid cell size) used to represent this behavioral strategy. This restricted detection of smaller aquatic microhabitats important to moose. Unfortunately, no finer-scale map currently exists andlimited our ability to study selection for aquatic microhabitats, which may be especially relevant in flatter, more swamp-like areas such as the Tanana and Innoko regions.

Based on our results and limitations encountered, we make three broad recommendations for future work regarding animal behavioral thermoregulation. First, future work should investigate the vulnerability and resilience of arctic-boreal animals to structural habitat changes as forage resources increase and thermal cover decreases (e.g., [52, 88]). For example, recent work on Alpine ibex (Capra ibex) - another heat-sensitive ungulate - indicates that male ibex response to minimize heat stress comes at the expense of optimal foraging [9]. Unfortunately, we did not have a detailed forage quality or biomass model calibrated for our study areas and hesitated to use categorical land cover maps because of criticisms regarding their use [17]. In Alaska, there is not a wide distinction between shrub classes in landcover maps that would enable us to determine if selected shrub habitats correspond to palatable species and foraging behavior. For instance, "shrub" in most vegetative classifications does not distinguish between shade forages (Salicaceae, Betula neoalaskana) and shade only (Alnus, B. nana) species, which is critical for parsing selection behavior. Moose maximize energy intake in the hottest parts of summer, so selection for forage biomass and quality plausibly overrides thermal stress and predation risk for a time. However, we were unable to directly assess this tradeoff due to data limitations. 
Second, we suggest testing for differences in female selection and movement relative to presence or absence of offspring. Such a distinction would connect nicely to calls to link behavior and movement to population outcomes $[10,59]$, especially when considering the thermal environment as survival and fitness often depend on the availability of suitable habitat to buffer against thermal extremes in a landscape [25].

Finally, a critical next step is to evaluate how habitat selection under thermal stress impacts individual fitness and population dynamics, as temperature plays an important role in limiting fecundity in other mammals $[18,93]$ including moose [50,62]. This is especially important as population responses to climate change can vary dramatically. For instance, Joly et al. [42] found the influence of climate on caribou herds in Alaska was not uniform, instead, western populations increased in size while northwestern populations declined as a result of intensity changes in the Pacific Decadal Oscillation. Similarly, using detailed demographic information for caribou (Rangifer tarandus), red deer (Cervus elaphus), and elk (C. canadensis) across the Northern Hemisphere, Post et al. [70] showed that that different population responses to climate varied in both direction and magnitude.

\section{Conclusion}

The impacts of climate change in arctic-boreal regions increase landscape heterogeneity through processes such as increased wildfire intensity and area burned, which can significantly alter the thermal environment available to an animal. Despite recognizing the importance of thermal conditions to animals, there is a distinct lack of research on how animals might respond to climate driven changes in thermal refugia. Our regional assessment provides insight on how Alaska moose may respond to changes in ambient temperature, where statewide annual temperatures are averaging an increase of $0.4{ }^{\circ} \mathrm{C}$ per decade and summer temperatures are projected to increase $2-5^{\circ} \mathrm{C}$ by midcentury [51]. Understanding habitat selection and movement patterns related to behavioral thermoregulation is a first step toward identifying areas capable of providing thermal relief for moose and other species impacted by climate change.

\section{Supplementary information}

Supplementary information accompanies this paper at https://doi.org/10 1186/s40462-020-00223-9.

Additional file 1: Supplementary 1: Temperature Validation.

Supplementary 2: Koyukuk males spline model results for elevation and temperature interaction. Supplementary 3: Interactive 3D plots of interaction between ambient temperature and canopy cover.

Supplementary 4: Used-Available Tables of Covariates. Supplementary 5: Regional Habitat Features. Figure 1e: Regional variation in elevation. ANOVA results comparing regional variation in elevation show that all regions vary from each other statistically $(F=2705, p<0.001)$. Figure $2 \mathrm{e}$ Regional variation in ambient temperature. ANOVA results comparing regional variation in ambient temperature show that all regions vary from each other statistically $(F=2705, p<0.001)$. With Tanana showing the highest temperatures, Innoko second, Koyukuk third, and Susitna fourth. Figure 3: Regional variation in cloud cover. ANOVA results show all regions vary from each other statistically ( $F=1472, p<0.001$ ), except Koyukuk and Susitna. Table 1E: Regional variation in fixes occurring in the rain Percent estimated proportionally comparing number of fixes in the rain to total number of fixes regionally.

\section{Abbreviations}

ABoVE: Arctic-boreal vulnerability experiment; ADFG: Alaska Department of Fish and Game; AMAP: Arctic Monitoring and Assessment Programme; CLR: Conditional-logistic regression; Env-DATA: Environmental-data automated track annotation; GEE: Generalized estimating equations; GPS: Global positioning system; IPCC: Intergovernmental Panel on Climate Change; LOOCV: Leave-one-out cross validation; NARR: North American regional reanalysis; NASA: National Aeronautics and Space Administration; NOAA: National Oceanic and Atmospheric Administration; QIC: Quasilikelihood under independence criterion; USGS: United States Geological Survey; RMSE: Root mean square error; RSAGA: R System for Automated Geospatial Analysis; S: Supplementary materials; Sp: Natural spline; SRI: Solar radiation index; SSF: Step selection function

\section{Acknowledgements}

We sincerely thank data owners who supplied the moose GPS-telemetry data used in this study as well as biologists whose edits contributed significantly to the clarity of this paper (specifically Tom Paragi, Graham Frye, Glenn Stout, Jeffrey Stetz, and Erin Julianus).

\section{Authors' contributions}

JSJ primary analyst and author; $\mathrm{MH}, \mathrm{PM}, \mathrm{SG}, \mathrm{AJHM}, \mathrm{NB}, \mathrm{KJ}, \mathrm{KAK}, \mathrm{SB}, \mathrm{LAV}$, and JUHE all contributed and advised on methodology, writing, and manuscript edits. The authors read and approved the final manuscript.

\section{Funding}

Funding for this work was provided by the National Aeronautics and Space Administration's (NASA) Arctic Boreal Vulnerability Experiment (ABoVE) grant numbers: NNX15AT89A, NNX15AW71A, NNX15AU20A, NNX15AV92A. The funders had no role in study design, data collection and analysis, decision to publish, or preparation of the manuscript.

\section{Availability of data and materials}

The GPS-telemetry data support the findings of this study are owned by Alaska Department of Fish and Game, National Park Service, and the Bureau of Land Management but restrictions apply to the availability of these data, which were used under license for the current study, and so are not publicly available.

\section{Ethics approval and consent to participate}

All capture protocols and handling protocols for moose in this study adhered to the Alaska Animal Care and Use Committee approval process (\#07-11) as well as the Institutional Animal Care and Use Committee Protocol (\#09-01).

Consent for publication

Not applicable.

\section{Competing interests}

The authors declare that they have no competing interests.

\section{Author details}

${ }^{1}$ Department of Natural Resources and Society, University of Idaho, Moscow, ID, USA. ${ }^{2}$ Wildlife Biology Program, Department of Ecosystem and Conservation Science, W.A. Franke College of Forestry and Conservation, University of Montana, Missoula, MT, USA. ${ }^{3}$ College of the Environment, University of Washington, Seattle, WA, USA. ${ }^{4}$ Department of Fish and Wildlife Sciences, University of Idaho, Moscow, ID, USA. ${ }^{5}$ School of the Environment, Washington State University, Pullman, WA, USA. ${ }^{6}$ Lamont-Doherty Earth 
Observatory, Columbia University, Palisades, NY, USA. ${ }^{7}$ National Park Service, Gates of the Arctic National Park and Preserve, Fairbanks, AK, USA. ${ }^{8}$ Alaska Department of Fish and Game, 1800 Glenn Hwy \#2, Palmer, AK, USA. ${ }^{9}$ Alaska Department of Fish and Game, Division of Wild life Conservation, 1300 College Rd, Fairbanks, Alaska, USA. ${ }^{10}$ Department of Forestry and Wildlife Management, Inland Norway University of Applied Sciences, Evenstad, Norway. ${ }^{11}$ McCall Outdoor Science School, University of Idaho, McCall, ID, USA.

Received: 13 May 2020 Accepted: 8 September 2020

Published online: 15 October 2020

\section{References}

1. Alaska Department of Fish and Game (ADFG). Our wealth maintained: a strategy for conserving Alaska's diverse wildlife and fish resources. Juneau: Alaska Department of Fish and Game; 2006. p. xviii+824. https://www.adfg alaska.gov/static/species/wildlife_action_plan/cwcs_full_document.pdf.

2. Arctic Monitoring and Assessment Programme (AMAP). Snow, water, ice, and permafrost in the Arctic: summary for policy-makers. Oslo; 2017. Retrieved from www.amap.no/swipa.

3. Arthur SM, Manly BFJ, Garner GW. Assessing habitat selection when availability changes. Ecology. 1996;77(1):215-27.

4. Beck PSA, Goetz SJ, Mack MC, Alexander HD, Jin Y, Randerson JT, et al. The impacts and implications of an intensifying fire regime on Alaskan boreal forest composition and albedo. Glob Chang Biol. 2011;17(9):2853-66. https://doi.org/10.1111/j.1365-2486.2011.02412.x.

5. Bourgoin G, Garel M, Blanchard P, Dubray D, Maillard D, Gaillard JM. Daily responses of mouflon (Ovis gmelini musimon $\times$ Ovis sp.) activity to summer climatic conditions. NRC Research Press. 2011;89(9):765-73. https://doi.org/ 10.1139/Z11-046

6. Boyce MS. Scale for resource selection functions. Divers Distrib. 2006;12(3): 269-76. https://doi.org/10.1111/j.1366-9516.2006.00243.x.

7. Boyce MS, Vernier PR, Nielsen SE, Schmiegelow FKA. Evaluating resource selection functions. Ecol Model. 2002;157(2-3):281-300.

8. Brenning A. Statistical geocomputing combining R and SAGA: the example of landslide susceptibility analysis with generalized additive models. In: Boehner J, Blaschke T, Montanarella L, editors. SAGA - seconds out (= hamburger Beitraege zur Physischen Geographie und Landschaftsoekologie), vol. 19; 2008. p. 23-32.

9. Brivio F, Zurmühl M, Grignolio S, Von Hardenberg J, Apollonio M, Ciuti S. Forecasting the response to global warming in a heat-sensitive species. Sci Rep. 2019;9(3048):1-16. https://doi.org/10.1038/s41598-019-39450-5.

10. Brodie JF, Post ES, Doak DF. Wildlife conservation in a changing climate. Chicago: University of Chicago Press; 2012.

11. Broders HG, Coombs AB, Mccarron JR. Ecothermic responses of moose (Alces alces) to thermoregulatory stress on mainland Nova Scotia. Alces. 2012;48:53-61.

12. Bump JK, Webster CR, Vucetich JA, Rolf O, Shields JM, Powers MD. Ungulate carcasses perforate ecological filters and create biogeochemical hotspots in forest herbaceous layers allowing trees a competitive advantage. Ecosystems. 2009;12(6):996-1007. https://doi.org/10.1007/s10021-009-9274-0.

13. Burkett VR, Wilcox DA, Stottlemyer R, Barrow W, Fagre D, Baron J, et al, Nonlinear dynamics in ecosystem response to climatic change: case studies and policy implications. Ecol Complex. 2005;2(4):357-94. https://doi.org/10. 1016/j.ecocom.2005.04.010.

14. Cameron RD, Smith T, Fancy SG, Gerhart KL, White RG. Calving success of female caribou in relation to body weight. Can J Zool. 1993;71(3):480-6.

15. Christie KS, Ruess RW, Lindberg MS, Mulder CP. Herbivores influence the growth, reproduction, and morphology of a widespread Arctic willow. PLoS One. 2014;9(7):1-9. https://doi.org/10.1371/journal.pone.0101716.

16. Clarke A, Rothery P. Scaling of body temperature in mammals and birds. Funct Ecol. 2008;22(1):58-67. https://doi.org/10.1111/j.1365-2435. 2007.01341.x

17. Coops NC, Wulder MA. Breaking the habit(at). Trends Ecol Evol. 2019;34(7): 585-7. https://doi.org/10.1016/j.tree.2019.04.013.

18. Corlatti L, Gugiatti A, Ferrari N, Formenti N, Trogu T, Pedrotti L. The cooler the better? Indirect effect of spring-summer temperature on fecundity in a capital breeder. Ecosphere. 2018;9(6):1-13. https://doi.org/10.1002/ecs2.2326.

19. Craiu RV, Duchesne T, Fortin D. Inference methods for the conditional logistic regression model with longitudinal data. Biom J. 2008;50(1):97-109.
20. Demarchi MW, Bunnell FL. Forest cover selection and activity of cow moose in summer. Acta Theriol. 1995;4(1):23-36.

21. Dodge S, Bohrer G, Weinzierl R, Davidson S, Kays R, Douglas D, et al. The environmental-DATA automated track annotation (Env-DATA) system: linking animal tracks with environmental data. Movement Ecology. 2013; 1(1):3. https://doi.org/10.1186/2051-3933-1-3.

22. Dormann CF, Elith J, Bacher S, Buchmann C, Carl G, Carr G, et al. Collinearity: a review of methods to deal with it and a simulation study evaluating their performance. Ecography. 2013;36(1):27-46. https://doi.org/10.1111/j.16000587.2012.07348.x

23. Dussault C, Ouellet J-P, Courtois R, Huot J, Breton L, Larochelle J. Behavioural responses of moose to thermal conditions in the boreal forest. Ecoscience. 2004:11(3):321-8.

24. Dussault C, Ouellet J, Courtois R, Huot J, Breton L, Jolicoeur H. Linking moose habitat selection to limiting factors. Ecography. 2005;28(5):619-28.

25. Elmore RD, Carroll JM, Tanner EP, Hovick TJ, Grisham BA, Fuhlendorf SD, et al. Implications of the thermal environment for terrestrial wildlife management. Wildl Soc Bull. 2017;41(2):183-93. https://doi.org/10.1002/wsb.772.

26. Epting J, Verbyla D. Landscape-level interactions of prefire vegetation, burn severity, and postfire vegetation over a 16-year period in interior Alaska. Can J For Res. 2005;35(6):1367-77. https://doi.org/10.1139/X05-060.

27. Fortin D, Beyer HL, Boyce MS, Smith DW, Duchesne T, Mao JS. Wolves influence elk movements: behavior shapes a trophic cascade in Yellowstone National Park. Ecology. 2005;86(5):1320-30.

28. Gelman A. Scaling regression inputs by dividing by two standard deviations. Stat Med. 2008;27(15):2865-73. https://doi.org/10.1002/sim.3107.

29. Gurarie E, Mahoney P, LaPoint S, Davidson S. Above: functions and methods for the animals on the move project of the Arctic boreal vulnerability experiment (ABoVE - NASA). R package version 0.11; 2018.

30. Hansen BB, Herfindal I, Aanes R, Sæther B-E, Henriksen S. Functional response in habitat selection and the tradeoffs between foraging niche components in a large herbivore. Nordic Society Oikos. 2009;118(6):859-72.

31. Hansen MC, Potapov PV, Moore R, Hancher M, Turubanova SA, Tyukavina A, et al. High-resolution global maps of forest cover change. Science. 2013; 342(6160):850-3. https://doi.org/10.1126/science.1244693.

32. Hayes RD, Harestad AS. Wolf functional response and regulation of moose in the Yukon. Can J Zool. 2000;78(1):60-6.

33. Hebblewhite $M$, Merrill E. Modelling wildlife-human relationships for social species with mixed-effects resource selection models. J Appl Ecol. 2008; 45(3):834-44. https://doi.org/10.1111/j.1365-2664.2008.01466.x.

34. Hijmans RJ. Raster: geographic data analysis and modeling. R package version 3.0-2; 2019. https://CRAN.R-project.org/package=raster.

35. Hosmer DW, Lemeshow S. Applied logistic regression. 2nd ed. New York: Wiley; 2000.

36. Intergovernmental Panel on Climate Change (IPCC). In: Core Writing Team, Pachauri RK, Meyer LA, editors. Climate Change 2014: Synthesis Report. Contribution of working groups I, II and III to the fifth assessment report of the intergovernmental panel on climate change. Geneva: IPCC; 2014. p. 151.

37. Johnson EA. Fire and vegetation dynamics: studies from the north American boreal forest. New York: Cambridge University Press; 1996.

38. Johnson $\mathrm{DH}$. The comparison of usage and availability measurements for evaluating resource preference. Ecology. 1980;61(1):65-71.

39. Johnstone JF, Chapin FSIII. Fire interval effects on successional trajectory in boreal forests of Northwest Canada. Ecosystems. 2006;9(2):268-77. https:// doi.org/10.1007/S10021-005-0061-2.

40. Johnstone JF, Hollingsworth TN, Chapin FSIII, Mack MC. Changes in fire regime break the legacy lock on successional trajectories in Alaskan borea forest. Glob Chang Biol. 2010;16(4):1281-95. https://doi.org/10.1111/j.13652486.2009.02051.x

41. Joly K, Craig T, Sorum MS, McMillan JS, Spindler MA. Variation in fine-scale movements of moose in the upper Koyukuk River drainage, northcentral Alaska. Alces. 2015;51:97-105.

42. Joly K, Klein DR, Verbyla DL, Rupp TS, Chapin FS III. Linkages between largescale climate patterns and the dynamics of Arctic caribou populations. Ecography. 2011;34(2):345-52. https://doi.org/10.1111/j.1600-0587.2010. 06377.x

43. Joly K, Sorum MS, Craig T, Julianus EL. The effects of sex, terrain, wildfire, winter severity, and maternal status on habitat selection by moose in northCentral Alaska. Alces. 2016;52:101-15.

44. Kasischke ES, Turetsky MR. Recent changes in the fire regime across the north American boreal region — spatial and temporal patterns of burning 
across Canada and Alaska. Geophys Res Lett. 2006;33(9). https://doi.org/10. 1029/2006GL025677.

45. Kasischke ES, Verbyla DL, Rupp TS, McGuire AD, Murphy KA, Jandt R, et al. Alaska's changing fire regime - implications for the vulnerability of its boreal forests 1. Candian J Forest Res. 2010;40(7):1313-24. https://doi.org/10. 1139/X10-098

46. Keating KA, Gogan PJP, Vore JM, Irby L. A simple solar radiation index for wildlife habitat studies. J Wildl Manag. 2007;71(4):1344-8. https://doi.org/10. 2193/2006-359.

47. Kelly R, Chipman ML, Higuera PE, Stefanova I, Brubaker LB, Sheng F. Recent burning of boreal forests exceeds fire regime limits of the past 10,000 years. Proc Natl Acad Sci. 2013;1 10(32):13055-60. https://doi.org/10.1073/pnas. 1305069110.

48. Kielland K, Bryant JP. Moose herbivory in taiga: effects on biogeochemistry and vegetation dynamics in primary succession. Oikos. 1998;82(2):377-83.

49. Leblond M, Dussault C, Ouellet JP. What drives fine-scale movements of large herbivores? A case study using moose. Ecography. 2010;33(6):1102-12. https://doi.org/10.1111/j.1600-0587.2009.06104.x.

50. Lenarz MS, Nelson ME, Schrage MW, Edwards AJ. Temperature mediated moose survival in northeastern Minnesota. J Wildl Manag. 2009;73(4):503-10 https://doi.org/10.2193/2008-265.

51. Markon C, Gray S, Berman M, Eerkes-Medrano L, Hennessy T, Huntington H, et al. Alaska. In: Reidmiller DR, Avery CW, Easterling DR, Kunkel KE, Lewis KLM, Maycock TK, Stewart BC, editors. Impacts, risks, and adaptation in the United States: fourth National Climate Assessment, volume II. Washington, DC: US Global Change Research Program; 2018. p. 11-85-1241.

52. Mason TH, Brivio F, Stephens PA, Apollonio M, Grignolio S. The behavioral trade-off between thermoregulation and foraging in a heatsensitive species. Behav Ecol. 2017;28(3):908-18.

53. McCain CM, King SRB. Body size and activity times mediate mammalian responses to climate change. Glob Chang Biol. 2014;20(6):1760-9. https:// doi.org/10.1111/gcb.12499.

54. McCann NP, Moen RA, Harris TR. Warm-season heat stress in moose (Alces alces). Can J Zool. 2013;91(12):893-8 Retrieved from http://www. nrcresearchpress.com/doi/abs/10.1139/cjz-2013-0175.

55. McLaren BE, Peterson RO. Wolves, moose, and tree rings on isle Royale. Science. 1994;266(5190):1555-8.

56. Melin M, Matala J, Mehtätalo L, Tiilikainen R, Tikkanen OP, Maltamo M, et al. Moose (Alces alces) reacts to high summer temperatures by utilizing thermal shelters in boreal forests - an analysis based on airborne laser scanning of the canopy structure at moose locations. Glob Chang Biol. 2014;20(4):111525. https://doi.org/10.1111/gcb.12405.

57. Mesinger FM, DiMego G, Kalnay E, Mitchell K, Shafran PC, Ebiuzaki W, et al. North american regional reanalysis. Am Meterological Soc. 2006;87(3):34360. https://doi.org/10.1175/BAMS-87-3-343

58. Montgomery RA, Redilla KM, Moll RJ, Van Moorter B, Rolandsen CM, Millspaugh $\mathrm{JJ}$, et al. Movement modeling reveals the complex nature of the response of moose to ambient temperatures during summer. J Mammal. 2019;100(1):169-77. https://doi.org/10.1093/jmammal/gyy185.

59. Morales JM, Moorcroft PR, Matthiopoulos J, Frair JL, Kie JG, Powell RA, et al. Building the bridge between animal movement and population dynamics. Philos Transact Royal Society B: Biol Sci. 2010;365(1550):2289-301. https:// doi.org/10.1098/rstb.2010.0082

60. Moreau G, Fortin D, Couturier S, Duchesne T. Multi-level functional responses for wild life conservation: the case of threatened caribou in managed boreal forests. J Appl Ecol. 2012;49(3):611-20. https://doi.org/10. $1111 / j .1365-2664.2012 .02134 . x$.

61. Muff S, Signer J, Fieberg J. Accounting for individual-specific variation in habitat-selection studies: efficient estimation of mixed-effects models using Bayesian or frequentist computation. J Anim Ecol. 2020;89(1):80-92. https:// doi.org/10.1111/1365-2656.13087

62. Murray DL, Cox EW, Ballard WB, Whitlaw HA, Lenarz MS, Custer TW, et al. Pathogens, nutritional deficiency, and climate influences on a declining moose population. Wildl Monogr. 2006;166:1), 1-30.

63. Mysterud A, Ims R. Functional responses in habitat use: availability influences relative use in trade-off situations. Ecology. 1998;79(4):1435-41. https://doi.org/10.2307/176754.

64. National Oceanic and Atmospheric Administration (NOAA). National Centers for environmental information, temperature summaries; 2019. [FIPS:02]. Retrieved from https://www.ncdc.noaa.gov/cdo-web/search, [Accessed 1/6/ 2020].
65. Nowacki GJ, Spencer P, Fleming M, Jorgenson T. Unified ecoregions of Alaska, U.S. Geol Surv Open File Rep. 2003. p. 02-297 (map). https://pubs.er. usgs.gov/publication/ofr2002297.

66. Pan W. Akaike's information criterion in generalized estimating equations. Biometrics. 2001;57(1):120-5.

67. Paragi TF, Kellie KA, Peirce JM, Warren MJ. Movements and Sightability of moose in game management unit 21E. Juneau: Alaska Department of Fish and Game; 2017.

68. Pekel JF, Cottam A, Gorelick N, Belward AS. High-resolution mapping of global surface water and its long-term changes. Nature. 2016;540(7633):41822. https://doi.org/10.1038/nature20584.

69. Porter, Claire, Morin, Paul; Howat, lan; Noh, Myoung-Jon; Bates, Brian; Peterman, Kenneth; Keesey, Scott; Schlenk, Matthew; Gardiner, Judith; Tomko, Karen; Willis, Michael; Kelleher, Cole; Cloutier, Michael; Husby, Eric; Foga, Steven; Nakamura, Hitomi; Platson, Melisa; Wethington, Michael, Jr.; Williamson, Cathleen; Bauer, Gregory; Enos, Jeremy; Arnold, Galen; Kramer, William; Becker, Peter; Doshi, Abhijit; D'Souza, Cristelle; Cummens, Pat; Laurier, Fabien; Bojesen, Mikkel, 2018, "ArcticDEM", https://doi.org/10.7910/ DVN/OHHUKH, Harvard Dataverse, V1, 2018, [Accessed 10/1/2018].

70. Post E, Brodie J, Hebblewhite M, Anders AD, Maier JAK, Wilmers CC. Global population dynamics and hot spots of response to climate change. Bioscience. 2009;59(6):489-97. https://doi.org/10.1525/bio.2009.59.6.7.

71. Prima MC, Duchesne T, Fortin D. Robust inference from conditional logistic regression applied to movement and habitat selection analysis. PLoS One. 2017;12(1):1-13. https://doi.org/10.1371/journal.pone.0169779.

72. R Core Team. R: a language and environment for statistical computing. Vienna: R Foundation for Statistical Computing; 2019. URL https://www.Rproject.org/.

73. Renecker LA, Hudson RJ. Seasonal energy expenditures and thermoregulatory responses of moose. Can J Zool. 1986;64(2):322-7.

74. Renecker LA, Schwartz CC. Food habits and feeding behavior. In: Franzmann, Schwartz CC, editors. Ecology and Management of the North American Moose 2nd ed. Washington, D.C.: Wildlife Management Institutions; 2007. p. 403-39.

75. Rönnegård L, Forslund P, Danell Ö. Lifetime patterns in adult female mass, reproduction, and offspring mass in semidomestic reindeer (Rangifer tarandus tarandus). Can J Zool. 2002;80(12):2047-55. https://doi.org/10.1139/ Z02-192.

76. Schwartz CC, Renecker LA. Nutrition and energetics. In: Franzmann, Schwartz CC, editors. Ecology and Management of the North American Moose. 2nd ed. Washington, D.C.: Wild life Management Institutions; 2007. p. $441-78$.

77. Screen JA. Arctic amplification decreases temperature variance in northern mid- to high-latitudes. Nat Clim Chang. 2014;4(7):577-82. https://doi.org/10. 1038/NCLIMATE2268.

78. Shenoy A, Johnstone JF, Kasischke ES, Kielland K. Persistent effects of fire severity on early successional forests in interior Alaska. For Ecol Manage. 2011;261(3):381-90. https://doi.org/10.1016/j.foreco.2010.10.021.

79. Speakman JR, Król E. Maximal heat dissipation capacity and hyperthermia risk: neglected key factors in the ecology of endotherms. J Anim Ecol. 2010; 79(4):726-46. https://doi.org/10.1111/j.1365-2656.2010.01689.x.

80. Street GM, Rodgers AR, Fryxell JM. Mid-day temperature variation influences seasonal habitat selection by moose. J Wild Manag. 2015;79(3):505-12. https://doi.org/10.1002/jwmg.859.

81. Testa JW, Becker EF, Lee GR. Movements of female moose in relation to birth and death of calves. Alces. 2000;36:155-62.

82. Therneau T. A package for survival analysis in S. version 2.38; 2015. https:// CRAN.R-project.org/package=survival.

83. Thompson DP, Barboza PS, Crouse JA, McDonough TJ, Badajos OH, Herberg AM. Body temperature patterns vary with day, season, and body condition of moose (Alces alces). J Mammal. 2019;100(5):1466-78.

84. Thompson DP, Crouse JA, Jaques S, Barboza PS. Redefining physiological responses of moose (Alces alces) to warm environmental conditions. Therm Biol. 2020;102581.

85. Timmermann HR, McNicol JG. Moose habitat needs. For Chron. 1988;64(3): $238-45$.

86. Thurfjell H, Ciuti S, Boyce MS. Applications of step-selection functions in ecology and conservation. Movement Ecology. 2014;2(4):1-12. https://doi. org/10.1186/2051-3933-2-4.

87. van Beest FM, Milner JM. Behavioural responses to thermal conditions affect seasonal mass change in a heat-sensitive northern ungulate. PLoS One. 2013;8(6). https://doi.org/10.1371/journal.pone.0065972. 
88. van Beest FM, Van Moorter B, Milner JM. Temperature-mediated habitat use and selection by a heat-sensitive northern ungulate. Anim Behav. 2012; 84(3):723-35. https://doi.org/10.1016/j.anbehav.2012.06.032.

89. van Beest FM, Rivrud IM, Loe LE, Milner JM, Mysterud A. What determines variation in home range size across spatiotemporal scales in a large browsing herbivore? J Anim Ecol. 2011;80(4):771-85. https://doi.org/10.1111/ j.1365-2656.2011.01829.x.

90. Vors LS, Boyce MS. Global declines of caribou and reindeer. Glob Chang Biol. 2009;15(11):2626-33. https://doi.org/10.1111/j.1365-2486.2009.01974.x.

91. Walker WH, Meléndez-Fernández OH, Nelson RJ, Reiter RJ. Global climate change and invariable photoperiods: a mismatch that jeopardizes animal fitness. Ecol Evol. 2019;9(17):10044-54. https://doi.org/10.1002/ece3.5537.

92. Walther GR. Community and ecosystem responses to recent climate change. Philos Transact Royal Society B: Biol Sci. 2010;365(1549):2019-24. https://doi.org/10.1098/rstb.2010.0021.

93. Wells K, O'Hara RB, Cooke BD, Mutze GJ, Prowse TAA, Fordham DA. Environmental effects and individual body condition drive seasonal fecundity of rabbits: identifying acute and lagged processes. Oecologia. 2016;181(3):853-64. https://doi.org/10.1007/s00442-016-3617-2.

94. Wickham H. ggplot2: elegant graphics for data analysis. New York: SpringerVerlag; 2016.

95. Wolken JM, Hollingsworth TN, Rupp TS, Chapin FS, Trainor SF, Barrett TM, et al. Evidence and implications of recent and projected climate change in Alaska's forest ecosystems. Ecosphere. 2011;2(11):1-35. https://doi.org/10. 1890/ES11-00288.1.

\section{Publisher's Note}

Springer Nature remains neutral with regard to jurisdictional claims in published maps and institutional affiliations.

Ready to submit your research? Choose BMC and benefit from:

- fast, convenient online submission

- thorough peer review by experienced researchers in your field

- rapid publication on acceptance

- support for research data, including large and complex data types

- gold Open Access which fosters wider collaboration and increased citations

- maximum visibility for your research: over $100 \mathrm{M}$ website views per year

At $\mathrm{BMC}$, research is always in progress.

Learn more biomedcentral.com/submissions 